\title{
Project Portfolio Management Capabilities of Strategic Initiatives and PMO Practices in Strategy Implementation: A Perspective of Dynamic Capability in Banking Industries in Indonesia
}

\author{
Mohammad Ichsan $^{1 *}$, Bahtiar Saleh Abbas ${ }^{1}$, Mohammad Hamsal', Jimmy Sadeli ${ }^{1}$ \\ ${ }^{1}$ Management Program, Bina Nusantara University \\ Email: ichsanpmp@yahoo.com
}

\begin{abstract}
Current business uncertainties in dynamic environment drive the banking industries to keep on in shape of competitive in the market. The organizations are forced to formulate and implement their strategic initiatives in a form of projects. Some of the project initiatives require prioritization, and we manage them by utilizing their unique resources capabilities in a form of project portfolio management (PPM) capability to deliver the outcome of it as a business performance by the organizations. Previous studies have found that moderating project management office (PMO) practices positively impact the project performances; hence, they should be affecting the final objective which is the business performance. This paper proposes a conceptual integrated research model of PPM capability, as realization of dynamic capability influences business performance perceived by the organization through an application of project management office practices in the organization
\end{abstract}

Keywords: dynamic capabilities, project portfolio management (PPM), project management office (PMO), perceived business performance

\section{Introduction}

Today's business uncertainties - such competitions, government regulation, economic environment, rapid technology growth, globalization, and customer demands (Wong et al. 2011) - they have led dynamic changes at the organization strategy level. Hamel (1996) in Patah, de Carvalho, and Laurindo (2005) states that in the recent economic turbulence, marked by changes that are intermittent, sudden, and sometimes uncontrolled, the company should be able to make quick action and responsive and innovative strategies for survival.

In context of financial services, especially banks, such conditions are inevitable. According to Oliver Wyman Report (2015), since the global financial crisis (GFC) happened in 2006 and 2008, the returns of financial firms have recovered, but not at pre-crisis levels, nor at the level of other industries (see Exhibit 1). Returns in the healthcare sector average 16\%; in technology, they average $18 \%$. Financial service returns now hover around the $7 \%$ average of utilities, as has been pictured in Figure 1. By having capital and liquidity regulations and interest rate policies working against financial firms, the management of financial services companies are 
under pressure to improve operational efficiency. Such a phenomenon shows the similarity in financial services in Indonesia. According to Indonesia's Finance Services Authority (2016) that during the 1997/98 crisis, the financial services experienced an all-encompassing restructuring process, which primarily focused on building up the function of supervision and applying good governance to the financial service sector. In order to support sounder economic growth, the establishment of the intermediation role of the FSS was taken into attention in the restructuring process. Therefore, in 2001-2008, Indonesia took pleasure in the average on annual growth of $5.2 \%$. Furthermore, the restructuring process made certain that the survival of this industry during the more recent global financial crisis (GFC) in 2008. The global financial crisis that has endured since 2008 has significantly affected the world trade volume also for Indonesia, and the excess has been even more articulated, taking into the consideration that deep economic downswing has affected China as a key export country for Indonesian goods. In fact, this global crisis was not the first time.

According to Oliver Wyman's Report (2015), the ranked source complexity in financial industries forces the company to be managed, such as heightened regulatory scrutiny and compliance requirements, provisions of electronic platforms and multi-channel interactions with customers, customer demands for wider and more bespoke product offerings, increasingly fragmented core infrastructure, and expanding geographical footprints. Such conditions drive the financial services industry, especially banking industries to recover or even sustain in their business by formulating strategies, with orientation of either cost leadership, market differentiation, or innovative differentiation (Porter 1980, 1985). Such challenges can be considered as environmental uncertainty in domain strategic management (Tan \& Lischert 1994; Sung et al., 2010; Wong et al., 2011).

Forward-thinking companies are quickly realizing that "just getting the job done" will not prepare them for sustainable business growth. Business success today requires organizations to provide products and services that keep their customers happy while constantly innovating to expand their market (Forrester 2013). Time to market is the critical factor when it comes to product innovation that challenges product innovations as explained by Aubry et al. (2007) and Aubry et al. (2009). Strategy implementation has always been crucial in objectifying the strategy formulation.

Economist Intelligence Unit (2013) has reported in the period of 2011-2013 that only the average of $56 \%$ of strategic initiatives have been successful implemented. This shows that there has been deviation in the strategy implementation. It means that companies failed to align the strategy with realization.

Figure 2 depicts the perceiveness of degree of success in performing strategic initiatives start declining whenever the strategies are executed. It shows that the strategies are not effectively aligned starting from very beginning, and it has the possibility to deteriorate the future strategy formulation, as the feeding lessons from the failed execution are the biggest among other phases.

To respond to those challenges and as part of a movement to increase the number of strategic initiatives to be implemented effectively, many organizations have been building their strategic initiatives of delivery capabilities to implement their strategy by utilizing their resources to be more competitive in the market (Barney, 1991) that can be measured by firm performance (Venkatraman \& Ramanujam 2986). On top of that, the dynamic capability (Teece et al. 1997) 


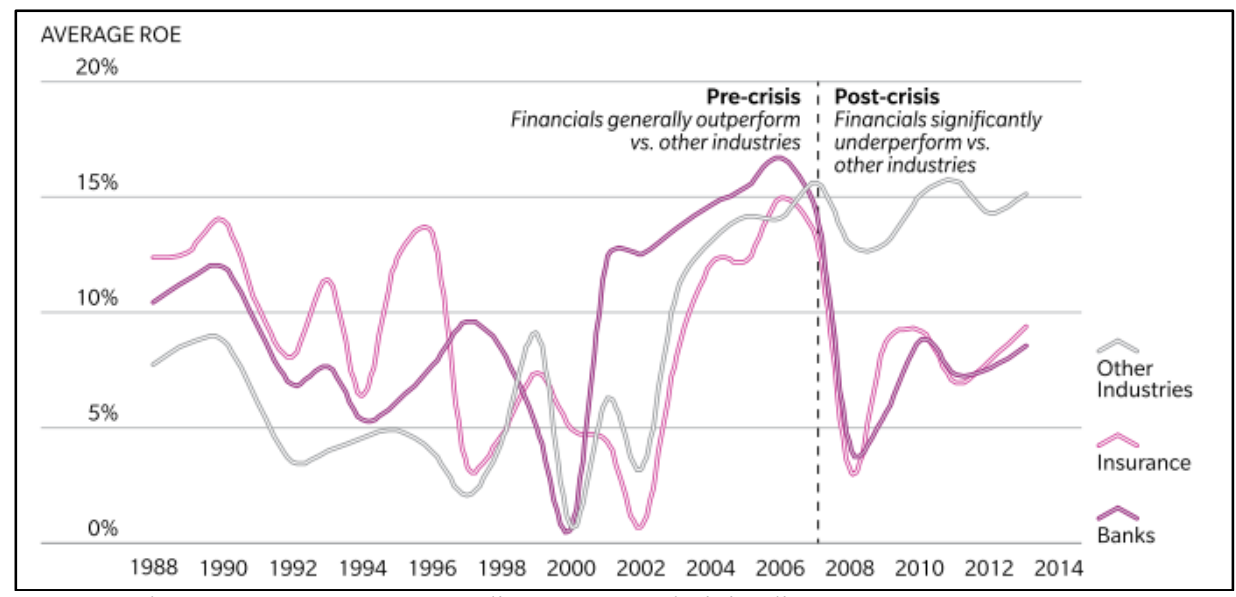

Source: Thomson Reuters Datastream, Oliver Wyman analysis in Oliver Wyman Report 2015

Figure 1. Return on Equity (RoE) - Financial Services vs. Non-financial services, 1988-2013

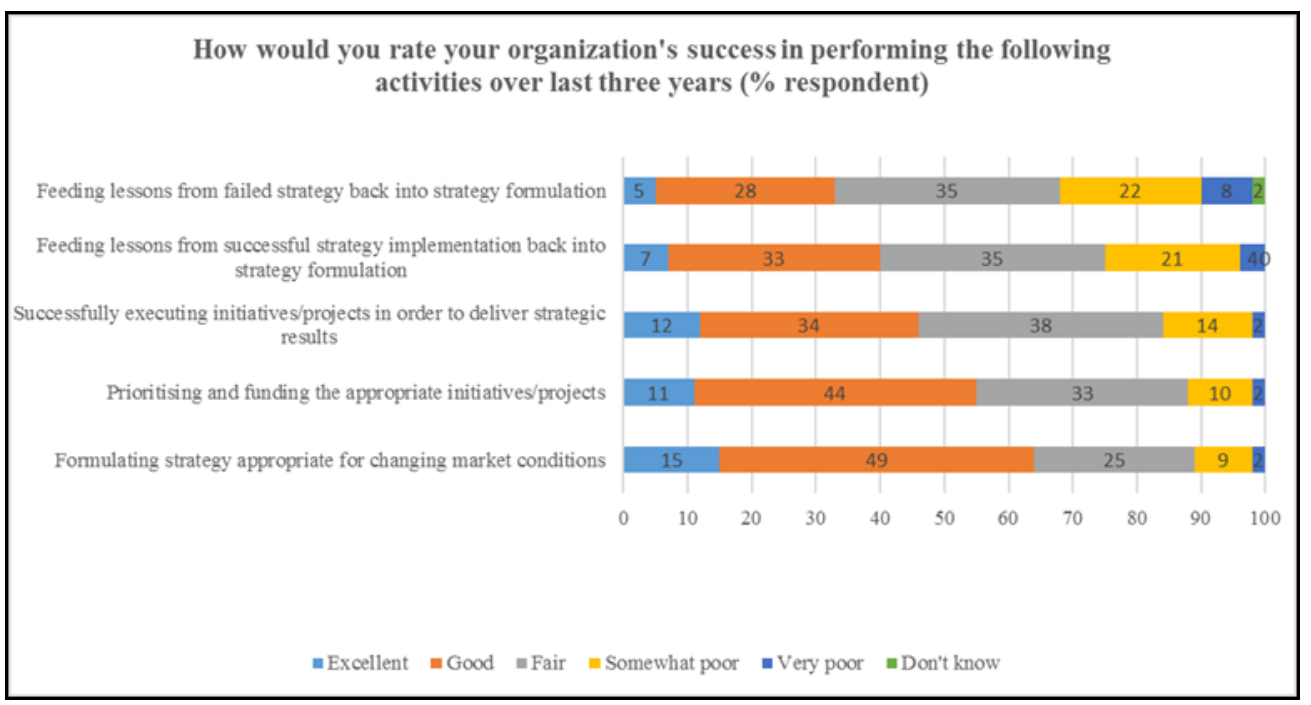

Source: Economist Intelligence Unit, 2013

Figure 2. Perceive of Organization's Success in Performing Strategic Initiatives 2011-2013

enables the organization to effectively respond to the dynamic environment where the organizations are competing and now getting more into attention.

Some strategic initiatives that are handled in a form of projects and they are sometimes managed simultaneously. Therefore, they need a structured management approach for project portfolios and project portfolios, as it has been argued by Dietrich \& Lehtonen (2005); Killen et al. (2008); Martinsuo \& Lehtonen (2007) in Beringer et al. (2012). Killen \& Hunt (2010) through their research have found out that the project portfolio management (PPM) capability is identified as dynamic capability that leads the companies to gain more competitive advantage. In order to implement the strategic initiatives in a form of projects, some of them have implemented a new organizational entity, the most common name which is an abbreviated Project Management Office or PMO (Aubry et al. 2009). Along the time the PMOs have been advancing, and their maturity level has been improving. 
Apart from the perceived needs to have PMO in the organization, there are identified challenges and questions of value of having PMO. According to Stanleigh (2006), in Singh et al. (2009), there are $75 \%$ of PMOs in the domain of the technology and information system which is shut down within 3 years of formation. Aubry et al. (2007) opine that PMO faces some severe challenges as the high number of PMOs is being shut down or being radically reconfigured and around half of PMOs are even being questioned for legitimacy within their organizations. Meanwhile, Hobbs \& Aubry (2007) argue only nearly 50\% of all PMOs have been perceived as too costly and as contributing little to the project and program performance. Furthermore, Hobbs et al. (2008) found that PMO structures are not stable in the organization and they are often reconfigured every year; hence, the implementation of PMOs is challenging for most organizations (Singh et al., 2009). According to Singh et al. (2009), the top five challenges are rigid corporate culture, lack of experienced PMs and PMO leadership, lack of appropriate change management strategy, lack of stakeholder's commitment to common methodology and tools for the PMO, and it is supported by Too \& Weaver (2013). Furthermore, Aubry et al. (2007) argue that a lot of questions and choices when it comes to the position of PMO are about an organization as well as unclear task description.

This study has the purpose to analyze how the strategic initiatives are formulated to respond to environmental uncertainty and implemented effectively using project portfolio management capabilities and project management office practice to achieve firm performance.

\section{Literature Review}

The essence of the whole theoretical framework is dynamic capability of an organization in implementing their strategic initiatives in a form of projects using project portfolio management capabilities that are moderated by the presence of practice of the project management office. The structure of literature review is proposed with 4 (four) major areas. The first area covers the core and fundamental theory that is covered by resourced based view and dynamic capabilities. The second area covers the context of strategic implementation starting with business uncertainty and followed by strategic initiatives formulation and strategic initiative implementation. The third area covers the application of dynamic capabilities in managing the implementation of strategic initiatives using a project management approach in a form of project portfolio management capabilities with its moderating factor which is the practice of the project management office. The fourth area covers the impact of dynamic capabilities in the organization that is indicated by perceived firm performance.

\section{Resource Based View (RBV)}

Previous research has found (Killen, 2008; Killen et al., 2008a; Killen et al., 2008b; Killen \& Hunt 2010) that the perspective of the resource-based view (RBV) and the dynamic capabilities are important to provide the unifying theoretical perspective for project portfolio management capabilities and explain its mechanism in which PPM contributes to competitive advantage. Hence, it is important to start with the fundamental theory, namely the resource based view (RBV). A notable feature of organizational strategy is the identification, development and maintenance of the major organizational resources that underpin competitive advantage as stated by O'Regan \& Ghobadian (2004) in Killen et al. (2008b). Wernerfelt (1984) defines resources as tangible and intangible assets which are tied semi-permanently to the form. Different from other industrial organization economics that counts on heavily on the aspects of the competitive 
advantage, the analysis of various resources owned by the organization is the center point of the RBV (Das \& Teng 2000). The RBV argues that resources are not uniform across competing organizations, and it uses this heterogeneity to explain the differing organizational success rates. Barney (1991) claims that only resources that are valuable, rare, inimitable, and nonsubstitutable can the best fundamental for sustainable competitive advantage. By having this condition, it is difficult for other organizations to copy or acquire it.

\section{Dynamic Capabilities}

According to Ethiraj et al. (2005) in Killen et al. (2008b), some of the literatures of the resource based view (RBV) allude to aspects of resources and capabilities interchangeably, while some others differentiate them. This research is referring to Teece et al. (1997), and it interprets capabilities as a specific type of resources in the organizations, which enables them to utilize other resources to perform activities that result in desired outcomes. According to Teece et al. (1997), dynamic capabilities are understood as firm's ability to integrate, build, and reconfigure internal and external competences to address rapidly changing environments. Leonard-Barton (1992) in Teece et al. (1997) argues that dynamic capability is also understood as ability to achieve new and innovative forms of competitive advantage given path dependencies and market positions.

\section{Business Uncertainty and Strategic Orientation}

Business organizations have to deal with unknown variables in uncertain environment while adopting or implementing their business strategy. Strategy formulation perspective shall consider that strategy, structure, and process must fit the environmental circumstances and these conditions may change overtime (Child 1972; Lawrence \& Lorsch 1967; Thompson 1967 in Tan et al. 1994). Tan et al. (1994) have defined the environmental measures, such as regulations, competitors, international aspect, technology, suppliers, customers, economy, socio-culture. Furthermore, Sung et al. (2010) proposed the type of uncertainty, such as customer demands, tastes and preferences, supplier action, market activities of competitors, deregulation and globalization, government regulations and policies, economic environment, design and information technologies. Meanwhile, Wong et al. (2011) argue that the environmental uncertainty contains customer preference, unpredicted supplier's performance, unpredicted competitors' action, and dynamic changes in production technologies. According to Porter (1980, 1985) by having a well-conducted strategic orientation (cost leadership, marketing differentiation, and innovative differentiation), business organizations can earn above-average returns. According to Gatignon \& Xuereb (1997) in Zhou et al. (2005b), strategic orientation is defined as a firm's strategic direction in creating proper behaviors so as to achieve superior performance. According to Kerin et al. (1992) in Durand \& Coeuderoy (2001) strategic orientations are a determinant of competitive sustainability. Apart from that, there are many options in characterizing the strategy; however, the typology that has been introduced by Porter $(1980,1985)$ is considered to be widely used and they are cost leadership, market differentiation, and innovation. For this study, the author applies the Porter's typology as it is widely used.

\section{Strategic Initiatives Implementation, PPM Capabilities, and PMO Practices}

Saunders et al. (2008) argue that all organizations experience a common challenge when implementing a new strategic initiative. It is how to successfully manage the changes that will 
occur as the new initiative is deployed. Some researchers found that organizations fail to execute up to 70 percent of their strategic initiatives (Beer \& Nohria 2000; Miller 2002) as cited in Saunders et al. (2008). Meanwhile, Hrebiniak (2006) argues that it is difficult to formulate the strategy, but it is even harder to execute or implement the strategy throughout the organization due to lack of execution of know-how and the ability to confront difficult organizational and political constraints that stand in the way of effective implementation (Neilson et al. 2008 in Smith 2011; Slater \& Olson 2000 in Smith 2011). Smith (2011) argues that there are several guidelines for successful strategy implementation, such as building a capable organization, marshalling resources, instituting policies, and procedures, adopting best practices and continuous improvement, instilling information and operating systems, providing rewards and incentives, instilling a corporate culture and leadership. Meanwhile, Saunders et al. (2008) study seven constructs of strategy deployment in his research, such as communicating the initiative, achieving buy-in, aligning implementation, learning, creating infrastructure for deployment, understanding the business drivers, and identifying deployment options. For the purpose of this study, the combination of seven constructs of Saunders et al. (2008) and eight guidelines from Smith (2011) are considered to be selected.

The study of Young et al. (2012) in exploring the effectiveness of project management and investment in the State of Victoria has concluded that there may be systemic deficiencies in projects over the past decades without any evidence of improvement in strategic goals. This study suggests that the deficiencies arise in the way projects have been selected and have managed the limit of the capability to realize strategic goals. It shows that once the strategic initiatives have been decided as projects, they are expected to be delivered, with little ability to put projects on hold or to cancel them. It is fully aligned with the previous studies from Daniel et al. (2014) where the idea has also been rooted from Killen (2008) and Killen \& Hunt (2010) that suggest the project portfolio management capabilities shall include the capability to cancel and reconfigure in-flight projects to ensure that the projects are still aligned with the strategicgoals.

Since this study will be referring to strategic initiatives of an organization as a project, it is important that the conceptual understanding of the project is thoroughly explained. Project Management Institute (2013a) defines project as temporary endeavor undertaken to create a unique product, service, or result, with characteristics of a group of activities and tasks that are exhibited by projects such as having specific objectives to be completed within certain specification, having defined start and end dates (Kerzner 2009; Munns \& Bjeirmi 1996; Brockhoff 2006).

According to PMI (2013a), portfolio is defined as projects, programs, sub portfolios, and operations managed as a group to achieve strategic objectives, while portfolio management is defined as the centralized management of one or more portfolios to achieve strategic objectives. Blichtfeldt \& Eskerod (2008) argue that PPM is defined as managerial activities that relate to initial screening, selection, and prioritization of project proposals, the concurrent reprioritization of the project in the portfolio, and the allocation and reallocation of resources according to priority. Based on Cooper et al. (1999) in Blichtfeldt \& Eskerod (2008) the recent research has made known of portfolio theories which are based on premise of limited capability (mainly due to adequate resources). The theories have been developed to the rationale of decision making theory based on certain criteria of (projects) alternatives and selection (or prioritization) of the projects that bring the most value to the organization. 
The theoretical framework of alignment of business strategy and project management has been thoroughly exposed by Milosevic and Srivannaboon (2006). Their research has formulated a framework for the nature of alignment. It has been developed by integrating Porter's generic strategy namely differentiation strategy, cost leadership strategy, and best-cost strategy (e.g. quality/cost), and project management elements of the Shenhar's strategic project leadership framework. Previous research has found (Killen, 2008; Killen et al., 2008a; Killen et al., 2008b; Killen \& Hunt 2010) that the perspective of resource-based view (RBV) and the dynamic capabilities are important in providing the unifying theoretical perspective for PPM capabilities and explaining its mechanism in which PPM contributes to competitive advantage. Apart from that, the research framework of Killen (2008) is aligned with dynamic capability, and the measurement of the consequences is within the PPM project performance from individual new products or services of development projects and not business performance as a typical measurement of impacts in the framework of dynamic capability. Meanwhile, Martinsuo \& Lehtonen (2007) assert that their study measured the project portfolio management efficiency, and it can be understood that the measurement is basically based on the organization capability to deliver their portfolio, such as alignment of project objectives with strategy, realization of company strategy in a form of projects, allocation of resources to projects that are aligned with strategy, supporting portfolio management to a strategy process and project prioritization.

The history of the project management office has been becoming popular since 1994 (Dai \& Wells, 2004) apart from their start since 1930s as it has been observed by Singh et al. (2009). Desouza \& Evaristo (2006) claim that PMO has been reported in the telecom, aerospace, and defense for a long time. Project Management Office (PMO) is defined as a management structure that standardizes the project-related governance process and facilitates the sharing of resources, methodologies, tools, and techniques. They also have responsibilities such as providing project management support functions to actually be responsible for the direct management of one or more projects (PMI, 2013a). Liou \& Yetton (2007) and Martin et al. (2007) in Singh et al. (2009) have defined PMO as a centralized layer of control between senior management and project management. Ward (2000) as quoted by Dai \& Wells (2004) defines PMO as an organizational entity established to assist project managers, teams and various management levels on strategic matters and functional entities throughout the organization in implementing project management principles, practices, methodologies, tools, and techniques. According to Hobbs \& Aubry (2007), Project Management Office (PMO) has several functions, such as monitoring and controlling project performance, development of project management competencies and methodologies, multi project management, strategic management, organization learning, and other functions, such as executing specialized tasks for project managers, managing customer interface and project management resources. Meanwhile, Dai $\&$ Wells (2004) argue that there are several project management (PMO) practices that can be applied in the organization, such as developing and maintaining project management standards and methods, developing and maintaining project historical archives, providing administrative support, providing human resources or staffing assistance, providing project management, consulting and mentoring, providing or arranging project management training.

\section{Firm Performance}

Performance is always a continuous and important theme in most branches of management, including strategic management, as it is interesting for both academic scholars and practitioners. Hult et al. (2004) define firm performance as the achievement of organizational goals related to profitability and growth in sales and market share, as well as the accomplishment of general 
firm strategic objectives. Meanwhile, Tseng (2010) based on consolidation of a previous study in her research concludes that firm performance can be defined as an integral improvement in the finance and performance (e.g. sales, profits or return on investment); an integral improvement in the relationship between an organization and its customer (e.g. market share, customer retention rates, customer satisfaction); an integral improvement in organizational effectiveness and efficiency (e.g. timing of launching new products or services, quality control or a project management procedure for developing new product); an integral improvement in human resources development (e.g. employee skills, commitment to technological leadership, personnel development); and an integral improvement in preparing for the future (e.g. quality/ depth of strategic planning, indicators of partnerships and alliances, anticipating and preparing changes in the environment). King \& Teo (2000), Miles et al. (2000), Tracey et al. (1999), Ward \& Duray (2000) in Nahm et al. (2004) argue that the firm performance shall include sales growth, return on investment, market share gain, and overall competitive positions.

According to Venkatraman \& Ramanujam (1986), the firm performances are categorized into three domains and they are within the domain of financial performance and the domain of operational performance. The domain of financial performance is considered as the center of firm performance as it uses the simple outcome based on a financial indicator and reflects the fulfillment of the economic goals of the firm. Typically, this approach is to examine indicators, such as sales growth, profitability, and earnings per share. For this study, the proposed indicators shall refer to a performance indicator for banking industries in Indonesia using CAMEL ratings (Nurazi \& Evans 2005), and they are capital, asset quality, management, earning, and liquidity.

\section{Conceptual Model and Hypotheses Development}

This study is going to seek the correlation among variables that are structured in the research modelasdepictedin Figure 3. Thevariableenvironmentaluncertaintyastheantecedentcorrelates with strategic orientation. Meanwhile, the strategic orientation variable mediates environmental uncertainty and variables of portfolio management capabilities of strategic initiatives and strategic initiatives implementation, while project portfolio management capabilities correspond to strategic initiatives implementation. Furthermore, the variable of perceived firm performance is as a consequence with variables of portfolio management capabilities of strategic initiatives and strategic initiatives implementation. Both correspondences are moderated with the variable of project management office (PMO) practices.

The conceptual research model is so structured considering the flow of how the strategic initiatives are initiated, formulated, implemented, and its impact on perceived firm performance. The context of dynamic capability is an underlying concept from project portfolio management capabilities that will affect the strategic initiatives implementation.

Prior to the implementation of strategic initiatives, the strategies will be formulated based on the strategic orientation (SO) to accommodate the environmental uncertainties (EU) that lead to the research question in knowing how EU influences $\mathrm{SO}$; hence, the following hypothesis is constructed.

\section{H1: Environmental uncertainty positively influences strategic orientation.}

Furthermore, the strategic orientation (SO) that formulates the firm's strategies shall be selected and prioritized considering the firm's capabilities to implement the strategies using the project 


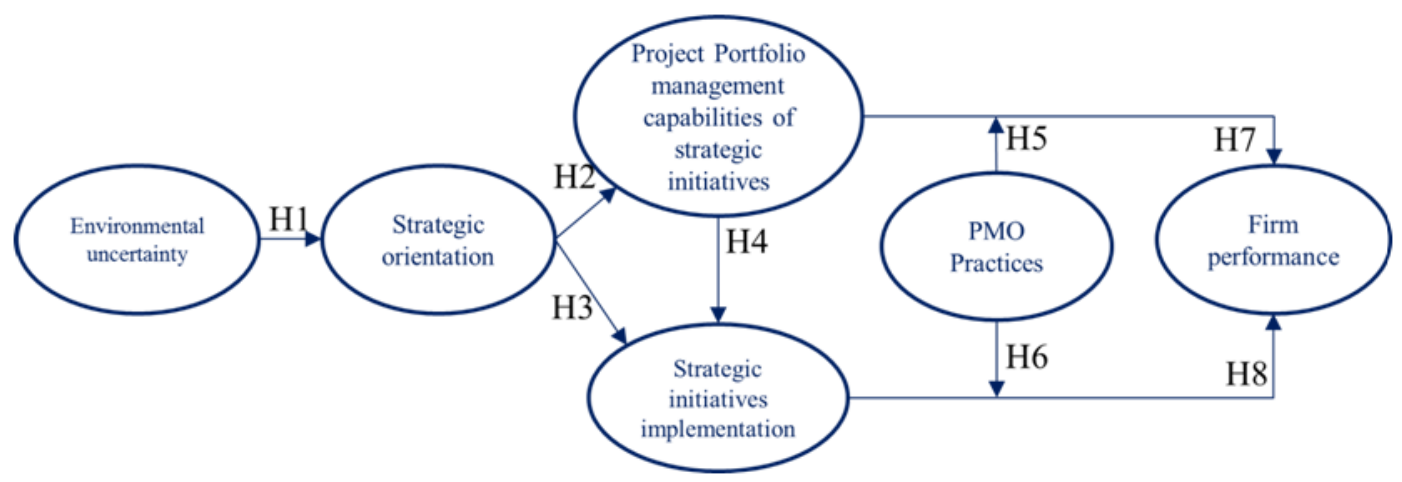

Figure 3. Proposed Conceptual Structural Model

Table 1. Content Analysis of the Originally Distributed Item Questionnaire

\begin{tabular}{|c|c|c|c|c|c|}
\hline No & Variables & Abbr. & Indicators & Item & Source \\
\hline 1. & $\begin{array}{l}\text { Environmental } \\
\text { uncertainty }\end{array}$ & $\mathrm{EU}$ & & 7 & $\begin{array}{l}\text { Tan \& Lischert (1994), } \\
\text { Wong et al. (2011), } \\
\text { Sung et al. (2010) }\end{array}$ \\
\hline 2. & Strategic orientation & $\mathrm{SO}$ & & 5 & $\begin{array}{l}\text { Porter (1980,1985), } \\
\text { Durand \& Coeurderoy } \\
\text { (2001), Zhou et al. } \\
\text { (2005), Chung et al. } \\
\text { (2012), Nobel et al. } \\
\text { (2002) }\end{array}$ \\
\hline 3. & $\begin{array}{l}\text { Strategic initiatives } \\
\text { implementation }\end{array}$ & SII & & 5 & $\begin{array}{l}\text { Hrebiniak (2006), } \\
\text { Saunders } \text { et al. (2008), } \\
\text { Thompson } \text { et al. (2008), } \\
\text { Smith (2011) }\end{array}$ \\
\hline \multirow[t]{4}{*}{4.} & \multirow[t]{4}{*}{$\begin{array}{l}\text { Portfolio of strategic } \\
\text { initiatives }\end{array}$} & \multirow[t]{4}{*}{ PPMC } & $\begin{array}{l}\text { Business objects drive } \\
\text { projects }\end{array}$ & 4 & \multirow{4}{*}{$\begin{array}{l}\text { Martinsuo \& Lehtonen } \\
\text { (2007), Killen et al. } \\
\text { (2008b), Killen \& Hunt } \\
\text { (2010), Daniel \& Ward } \\
\text { (2014) }\end{array}$} \\
\hline & & & $\begin{array}{l}\text { Multiple dynamic } \\
\text { prioritization }\end{array}$ & 1 & \\
\hline & & & $\begin{array}{l}\text { Dynamic balancing of risk } \\
\text { and reward }\end{array}$ & 2 & \\
\hline & & & $\begin{array}{l}\text { Cancel/reconfigure inflight } \\
\text { project }\end{array}$ & 1 & \\
\hline 5. & $\begin{array}{l}\text { Project management } \\
\text { office practices }\end{array}$ & PMOP & & 6 & $\begin{array}{l}\text { Dai \& Wells (2004), } \\
\text { Aubry \& Hobbs (2010), } \\
\text { Neaverth (2015) }\end{array}$ \\
\hline 6. & $\begin{array}{l}\text { Perceived firm } \\
\text { performance }\end{array}$ & PBP & & 5 & $\begin{array}{l}\text { Venkatraman \& } \\
\text { Ramanujam (1986), } \\
\text { Marques \& Simon } \\
\text { (2006), Tseng (2010) }\end{array}$ \\
\hline & & & Total & 36 & \\
\hline
\end{tabular}

portfolio management capabilities of strategic initiatives (PSI) as previous studies from Killen et al. (2008) and Killen \& Hunt 2010) lead to research questions of how the SO influences the PSI, where the next hypotheses are herewith built.

H2: Strategic orientation positively affects project portfolio management capabilities of strategic initiatives.

H3: Strategic orientation positively affects strategic initiatives implementation. 
After the strategic initiatives are selected through PSI, then the implementation of strategic initiatives (SII) will take place, which the research question to this relationship is how the PSI influences SII; hence, the suggested hypothesis is:

H4: Portfolio management capabilities of strategic initiatives positively affect strategic initiatives implementation.

Moreover, the strategic initiatives implementation is concluded by the selection process within the project portfolio of management capabilities and implemented, and the management of this implementation is through a project management approach. Therefore, previous studies of Dai \& Wells (2001), Stewart (2001), and Neaverth (2015) have shown that the project management office practices apply project management governance that positively influences project performance. As this study considers strategic initiatives as projects, then there is a need to prove whether PMO practices (PMOP) positively influence both relationships of strategic initiatives implementation (SII) to perceived firm performance and the project portfolio of management capabilities of strategic initiatives (PSI) and perceived form performance. This leads to the following hypotheses:

H5: Project management office practices moderate the relationship between portfolio management capabilities of strategic initiatives and perceived firm performance.

H6: Project management office practices moderate the relationship between strategic initiatives implementation and perceived firm performance.

Finally, as the expected result of the strategic initiatives implementation to bring positive performance of the firm, it is important to explore how the effective strategic initiatives implementation influences the firm performance that is perceived by the $\mathrm{C}$-suites and senior managers of the companies. This thought leads to the following hypotheses.

H7: Portfolio management capabilities of strategic initiatives (PSI) positively influence perceived firm performance.

H8: Strategic initiatives implementation (SII) positively influences perceived firm performance.

\section{Research Method}

The used method in this research is a non-experimental correlational study to determine how the independent variables explain the dependent variable as per proposed conceptual research model (Aubry \& Hobbs, 2011; Singh et al., 2009 in Neaverth 2015). The research design seeks to provide results to add empirical evidence for the relationship of environment uncertainty, strategic orientation, project portfolio management capability, strategic initiative implementation, and perceived firm performance. Additionally, this design requires the collection of data from a single reference point in time and is a cross-sectional correlational research design using a statistical analysis based on a positivist perspective as a basis philosophy underlying this research, which is often referred to as the research paradigm (Collis \& Hussey 2013 in Aubry 2008). The positivist approach is generally viewed as scientific, objective, experimentalist, traditional, and quantitative. Positivists generally believe that there is a truth that can be discovered through objective quantitative research. Therefore, this research is using a quantitative approach. The unit of analysis used for this research is the companies, and 
the object of analysis is executives or senior management from respective companies, as the dependent variable is firm performance (Venkatraman \& Ramanujam 1986; Hult et al. 2004; Nahm et al. 2004; Marques \& Simon 2006; Tseng 2010).

\section{Operationalization of Variables}

Based on previous research and the proposed conceptual research model, the authors proposea questionnaire. The questions or statements used in the questionnaire mostly refer to the questionnaire used from previous research as they are proven and empirically tested. The measurement of each item uses an even numbered Likert scale agreement or disagreement with the scale of 1 to 6 , where 1 indicates strong disagreement and 6 represents strong agreement with questions or statements. The structure of the variables is shown in Table 1.

\section{Sampling Method and Determining Sample Size}

This study will be performed using an empirical and quantitative approach. The proposed sampling frame is a formal list of banks in Indonesia that are registered in Otoritas Jasa Keuangan (OJK 2015). As the number of banks is known, this study will do census instead of sampling. The unit of analysis is banks as companies, and the object of analysis will be either corporate executives or senior managers of corporate strategy or the head of PMO. The identified population of the companies is 118 banks ( 26 regional banks, 10 foreign banks, and 82 local commercial banks).

\section{Data Collection and Analysis}

The data will be collected through a survey that will be using structured questionnaires. The questionnaires will be sent to the banking industry company as has been listed in a sampling frame using online survey tools such as Surveymonkey.com and Google Form or through emails to a respective object of analysis, while the performance data will be gathered from secondary data (OJK or any other reliable and relevant sources). The proposed method of analysis is using the structured equation model (SEM), as this study intends to explore how the variables are having an influence as an integrated model. The proposed analysis tool is Partial Least Square (PLS) as the number of population is relatively small.

\section{Discussion}

The proposed framework is conceptual, and it is still to be empirically tested. One of the novelties of this research is that the variables of PPM capabilities and PMO practices, which are normally measured in a unit of analysis of projects, are now measured up to an organization level which will affect a broader spectrum of impacts, not only in project based but also in organization based. The identified variables need to be tested using collected data and analyzed using a structured equation model as this research will also explore how those variables are related to each other. Depending on the number of collected data, both analysis tools LISREL (Linear Structural Relation) and PLS (Partial Least Square) can be considered to be used. 


\section{Research Importance and Benefits}

The financial industries are relatively fragile and highly influenced by the business environment uncertainties. Tight market competition, high demand of product and services from customers, and heightened regulatory scrutiny \& compliance requirements from the government influence the business in financial sectors. The right and timely decisions to implement the strategy for overcoming the business dynamics are very essential to banking industries.

This research seeks to contribute to the field of project management by providing additional contribution to the theory of dynamic capabilities in project management and practical applications of the thesis contribution in the field of strategic management and project management, especially in application of project portfolio management and the project management office. The contribution of the theory of this research will build upon prior research of project portfolio management capabilities (Killen \& Hunt 2010; Killen et al., 2008a; Killen et al. 2008b) and the project management office (Dai \& Wells 2004; Aubry et al. 2007), Aubry et al. 2009).

\section{References}

Aaltonen, P. 2007. Adoption of strategic goal: Exploring the success of strategy implementation through organizational activities. $\mathrm{PhD}$ dissertation. Helsinki University of Technology.

Ahadzie, D.K. 2007. A model for predicting the performance of project managers in mass house building projects in Ghana. Ph.D dissertation. University of Wolverhampton.

Aubry, M., Hobbs, B. \& Thuillier, D. 2007. A new framework for understanding organizational project management through the PMO. International Journal of Project Management, 25(4), pp.328-336.

Aubry, M., Hobbs, B. \& Thuillier, D. 2009. The contribution of the project management office to organizational performance. International Journal of Managing Projects in Business, 2(1), pp.141-148.

Aubry, M. \& Hobbs, B. 2010. A fresh look at the contribution of project management to organizational performance. Project Management Journal, 42(1), pp.3-16.

Bacccarini, D. 1999. "The Logical Framework Method for Defining Project Success", Project Management Journal, vol. 30, no. 4, pp. 25-32.

Barney, J. 1991. Firm Resources and Sustained Competitive Advantage. Journal of Management, 17(1), pp.99-120.

Barreto, I. 2009. Dynamic Capabilities: A Review of Past Research and an Agenda for the Future. Journal of Management, 36(1), pp.256-280. 
Beringer, C., Jonas, D. \& Kock, A. 2013. Behavior of internal stakeholders in project portfolio management and its impact on success. International Journal of Project Management, 31(6), pp.830-846.

Blichfeldt, B.S. \& Eskerod, P. 2008. Project portfolio management - There's more to it than what management enacts. International Journal of Project Management, 26(4), pp.357-365.

Boston Consulting Group. 2013. The PMO Imperative. Strategic Initiative Management. The Boston Consulting Group Inc.

Brockhoff, K. 2005. On the novelty dimension in project management. Project Management Journal, 37(3), pp.26-36.

Chung, Y.C. et al. 2012. The correlation between business strategy, information technology, organizational culture, implementation of CRM and firm performance in a high-tech industry. South African Journal of Industrial Engineering, 23(2), pp.1-15.

Crawford, L. 2005. Developing organizational project management capabilities: Theory and practice. Project Management Journal, 37(3), pp.74-97.

Dai, C.X. \& Wells, W.G. 2004. An exploration of project management office features and their relationship to project performance. International Journal of Project Management, 22(7), pp.523-532.

Daniel, E.M., Ward, J.M. \& Franken, A. 2014. A dynamic capabilities perspective of IS project portfolio management. Journal of Strategic Information Systems, 23(2), pp.95111.

Das, T.K. \& Bing.-S.T., 2000. A Resource-Based Theory of Strategic Alliances. Journal of Management, (1), pp.31-62.

Desouza, K.C. \& Evaristo, J.R. 2006. Project management offices: A case of knowledgebased archetypes. International Journal of Information Management, 26(5), pp.414-42.

Eisenhardt, K.K.M. \& Martin, J.J.A.. 2000. Dynamic capabilities: What are they? Strategic Management Journal, 21(10-11), pp.1105-1121.

Forrester Consulting. 2013. Strategic PMOs Play A Vital Role In Driving Business Outcomes. (November).

Gravetter, F.J. \& Wallnau, L.B. 2007. Statistics for the behavioral science. Seventh edition. Belmont: Thomson Wadsworth.

Hair J.F., Black, W.C., Babin, B.J., Anderson, R.E., \& Tatham, R.L. 2006. Multivariate data analysis. Sixth edition. Upper Saddle Revier, New Jersey: Pearson Prantice Hall.

Hill, G.M. 2004. Evolving the project management office: A complex competency continuum. Information Systems Management, 21(4), pp.45-51. 
Hobbs, B. \& Aubry, M. 2007. A multi-phase research program investigating project management offices (PMOs): the results of phase 1. Project Management Journal 38(1), 74.

Hobbs, B., Aubry, M. \& Thuillier, D. 2008. The project management office as an organizational innovation. International Journal of Project Management, 26(5), pp.547-555.

Hoque, Z. 2004. A contingency model of the association between strategy, environmental uncertainty, and performance measurement: Impact on organizational performance. International Business Review, 13(4), 485-502.

Hrebiniak, L.G. 2006. Obstacles to effective strategy implementation. Organizational Dynamics, 35(1), pp.12-31.

Hult, G.T.M., Hurley, R.F. \& Knight, G.A. 2004. Innovativeness: Its antecedents and impact on firm performance. Industrial Marketing Management, 33(5), pp.429-438.

Indonesia Financial Services Authority. 2016. Indonesian Financial Services Sector Master Plan 2015-2019: Fostering growth and addressing challenges in the financial services sector, today and tomorrow. Jakarta: Indonesia Financial Services Authority.

Kerzner, H. 2009. Project management: a systems approach to planning, scheduling, and controlling 10th ed., Hoboken, New Jersey: John Wiley \& Sons, Inc.

Killen, C. 2008. Project portfolio management for product innovation in services and manufacturing industries. $\mathrm{PhD}$ dissertation. Macquarie University.

Killen, C.P., Hunt, R.A. \& Kleinschmidt, E.J. 2008a. Project portfolio management for product innovation. International Journal of Quality \& Reliability Management, 25(1), pp.24-38.

Killen, C.P., Hunt, R.A. \& Kleinschmidt, E.J. 2008b. Learning investments and organizational capabilities: Case studies on the development of project portfolio management capabilities. International Journal of Managing Projects in Business, 1(3), pp.334-351.

Killen, C.P. \& Hunt, R.A. 2010. Dynamic capabilities through project management in service and manufacturing industries. International Journal of Managing Projects in Business, 3(1), pp.157-169.

Martinsuo, M. \& Lehtonen, P. 2007. Role of single-project management in achieving portfolio management efficiency. International Journal of Project Management, 25(1), pp.5665 .

Marques, D.P. \& Simon, F.J.G. 2006. The effect of knowledge management practices on firm performance. Journal of Knowledge Management, 10(3), pp.143-156.

Milosevic, D.Z. \& Srivannaboon, S. 2005. A theoretical framework for aligning project management with business strategy. Project Management Journal, 37(3), pp.98-110. 
Munns, A.K. \& Bjeirmi, B.F. 1996. The role of project management in achieving project success. International Journal of Project Management, 14(2), pp.81-87.

Nahm, A. Y., Vonderembse, M. A., \& Koufteros, X.A. 2004. The impact of organizational culture on time-based manufacturing and performance. Decision Sciences, 35(4), pp.579-607.

Neaverth, M. 2015. Project Management and governance in the project management office (PMO): Analysis of the variables associated with project success. Ph.D dissertation. Capella University.

Noble, C.H., Sinha, R.K. \& Kumar, A. 2002. Market Orientation and Alternative Strategic Orientations: A Longitudinal Assessment of Performance Implications. Journal of Marketing, 66(4), pp.25-39.

Nurazi, R. \& Evans, M. 2005. An Indonesian Study of the Use of CAMEL(S) Ratios as Predictors. Journal of Economic and Social Policy, 10(1), pp.1-23.

Oliver Wyman. 2015. Managing complexity: The state of the financial services industry 2015. Oliver Wyman.

Patah, L.A., de Carvalho, M.M., \& Laurindo, F.J.B. 2015. 'Aligning Project Management Office and Strategy: A Brazilian Case Study', Resources Management Association International Conference. San Diego, 15-18 May 2005. PA: Idea Group Publishing.

Pinkerton, W. J. 2003. Project Management: Achieving Project Bottom-line Success, McGraw-Hill, New York.

Porter, M. 1980. Competitive strategy. New York: Free Press.

Porter, M.E. 1981. The contributions of industrial organization to strategic management. Academy of Management Review, 6(4), pp.609-620.

Porter, M. 1985. Competitive advantage. New York: Free Press.

Porter, M. 2011. What is strategy? HBR's 10 must reads: On strategy. Boston, Mass.: Harvard Business Review Press, pp.1-37.

Project Management Institute. 2013a. A Guide to the Project Management Body of Knowledge (PMBoK ${ }^{\circledR}$ Guide)-Fifth Edition. Pennsylvania, PA: Project Management Institute Inc.

Project Management Institute. 2013b. The Impact of PMOs on Strategy Implementation. PMI's Pulse of the Profession In-Depth Report. Pennsylvania: Project Management Institute.

Project Management Institute. 2013c. PMO Frameworks. PMI's pulse of the profession. Pennsylvania: Project Management Institute. 
Project Management Institute. 2013d. Pulse of the Profession ${ }^{T M}$ in-Depth Report: Portfolio Management. Pennsylvania: Project Management Institute.

Saunders, M., Mann, R., \& Smith, R. 2008. Implementing strategic initiatives: a framework of leading practices. International Journal of Operations \& Production Management, 28(11), pp.1095-1123.

Salunke, S., Weerawardena, J., \& McColl-Kennedy, J.R. 2011. Towards a model of dynamic capabilities in innovation-based com- petitive strategy : insights from project-oriented service firms. Industrial Marketing Management, 40(8), pp. 1251-1263.

Sekaran, U. \& Bougie, R. 2010. Research method for business: A skill building approach, Fifth Edition. Chichester: Wiley.

Singh, R., Keil, M. \& Kasi, V. 2009. Identifying and overcoming the challenges of implementing a project management office. European Journal of Information Systems, 18(5), pp.409-427.

Smith, E.E. 2011. Perceptions Regarding Strategy Implementation Tasks in Selected Industries: A South African Perspective. International Journal of Business and Commerce, 1(4), pp.22-45.

Stewart, J. 2010. The Role of the Project Management Office on Information Technology Project Success. Ph.D dissertation. Capella University.

Sung, T.-J., Lu, Y.-T. \& Ho, S.-S. 2010. Time-based strategy and firm performance under environmental uncertainty: An empirical study of design firms in Taiwan. International Journal of Design, 4(3), pp.29-42.

Tan, J.J., Litschert, R.J. \& Ven, D. 1994. Environment-Strategy Relationship and Its Performance Implications: an Empirical Study of the Chinese Electronics Industry. Strategic Management Journal, 15(5), pp.1-20.

Teece, D.J., Pisano, G. \& Shuen, A. 1997. Dynamic Capabilities and Strategic Management. Strategic Management Journal, 18(7), pp.509-533Thompson, A., Strickland, A. \& Gamble, J. 2010. Crafting and executing strategy. Boston: McGraw-Hill/Irwin.

Thomas, H. \& Pollock, T. 1999. From I-O Economics' S-C-P Paradigm through Strategic Groups to Competence-Based Competition: Reflections on the Puzzle of Competitive Strategy. British Journal of Management, 10 (July 2016), pp.127-140.

Tseng, S.-M. 2010. The correlation between organizational culture and knowledge conversion on corporate performance. Journal of Knowledge Management, 14(2), pp.269-284.

Venkatraman, N. \& Ramanujam, V. 1986. Measurement of Firm performance in Strategy Research : A Comparison of Approaches. The Academy of Management Review, 11(4), pp.801-814. 
Ward, J. \& Daniel, E. 2013. The role of project management offices (PMOs) in IS project success and management satisfaction. Journal of Enterprise Information Management, 26(3), pp.316-336.

Wernerfelt, B. 1984. A resource based view of the firm. Strategic Management Journal, 5(2), pp.171-180.

Wijayanto, S.H. 2008. Structural equation modelling dengan LISREL 8.8: Konsel dan tutorial. Yogyakarta: Graha Ilmu.

Wong, C.Y., Boon-Itt, S., \& Wong, C.W.Y. 2011. The contingency effects of environmental uncertainty on the relationship between supply chain integration and operational performance. Journal of Operations Management, 29(6), pp.604-615.

Young, R. et al. 2012. Is strategy being implemented through projects? Contrary evidence from a leader in New Public Management. International Journal of Project Management, 30(8), pp.887-900.

Zhou, K.Z., Yim, C.K. \& Tse, D.K. 2005a. The Effects of Strategic Orientations on Technology- and Market-Based Breakthrough Innovations. Journal of Marketing, 69(2), pp.42-60.

Zhou, K.Z., Gao, G.Y., Yang, Z., Zhou, N. 2005b. Developing strategic orientation in China: Antecedents and consequences of market and innovation orientations. Journal of Business Research, 58(8), pp.1049-1058.

Zwikael, O. \& Smyrk, J. 2012. A General Framework for Gauging the Performance of Initiatives to Enhance Organizational Value. British Journal of Management, 23(SUPPL. 1), pp.6-22. 